\title{
SEQUENCE STRATIGRAPHIC INTERPRETATION OF THE CHILGA BASIN SEDIMENTS, NORTHWEST ETHIOPIA
}

\author{
Mulugeta Feseha \\ Department of Earth Sciences/Institute of Development Research, Addis Ababa University \\ PO Box 1176, Addis Ababa, Ethiopia. E-mail: mulufy@idr.aau.edu.et
}

\begin{abstract}
Sequence stratigraphic interpretation of passive margins and marine environments reveal stratigraphic records that result from the influence of long-term change in eustatic sea level, tectonic subsidence, and climate. On the other hand, sequence stratigraphic interpretation of continental rift basin sediments reveal stratigraphic records that are dominantly controlled by short-term local tectonic conditions and climatic fluctuations. The Chilga continental rift basin, located in northwest Ethiopia, consisting of sediments composed of claystones, siltstones and silty sandstones, volcanic ashes, lignite beds, and vertebrate and plant fossil-rich sandstones provides ample information for such a sequence stratigraphic interpretation. This paper presents a sequence stratigraphic interpretation of the Chilga basin sediments using integrated approaches such as regional stratigraphic correlation and interpretation of depositional environment derived from petrography, $\mathrm{x}$-ray diffraction analysis, and lithologic associations. Results indicate that the Chilga basin preserves three $4^{\text {th }}$ order sedimentary cycles within 1.0 Ma. Sequence stratigraphic analysis of the Chilga continental rift basin is a working model for the many unstudied Ethiopian rift and non-rift basin sediments, which are dominantly composed of fine-grained sediments.
\end{abstract}

\section{Key words/phrases: Basin, Chilga, continental rift, Ethiopia, sequence stratigraphy}

\section{INTRODUCTION}

Sequence stratigraphic studies of fluvio-lacustrine sediments have been carried out by various researchers (Picard and High, 1981; Lambiase and Bosworth, 1995; Magee et al., 1995; Bohacs and Suter, 1997; Purser and Bosence, 1998; Morley, 1999; Carroll and Bohacs, 2000; Contreras and Scholz, 2000; Hanson et al., 2001; Mahboubi et al, 2001) including studies of East African rift sediments (Baker, et al., 1972; Beadle, 1981; Lambiase, 1989; Mbede, 1991; Pickard, 1994; Smith, 1994). However, few studies have presented an integrated approach that incorporates stratigraphic correlation, geochronology, and depositional environment analysis for sequence stratigraphic interpretation.

The Chilga basin is a continental rift basin with isolated outcrops of sedimentary and volcanic basin fills separated by faults. Its sequence stratigraphy has not previously been studied in great detail. Sediments filling the Chilga basin are composed of volcanic ashes, lignite beds, silty sandstones, silty claystones, and vertebrate and floral fossil bearing sandstones. Continental rift basins such as the Chilga basin, which contain outcrops that can be correlated with marker ash beds, and as such can be dated with a suitable dating method, provide a unique opportunity to understand the tectonic evolution, climatic change and stratigraphic framework of rift basins. This approach will also provide a working model for the yet-unstudied Oligocene-to-Recent age rift basin sediments in Ethiopia.

Radioisotopic and paleomagnetic dating techniques were used to constrain the age of the basin filling sediments and the underlying basaltic rocks. Results indicate that the Chilga sediments were deposited between 27-28 Ma (Mulugeta Feseha et al., 2001; Mulugeta Feseha, 2002; Kappelman et al., 2003). Petrographic and xray diffraction analysis techniques were used to interpret the depositional environment of the finegrained Chilga sediments. Results indicate that the Chilga sediments are composed of framework grains of mainly unaltered plagioclase, potassium feldspars, and volcanic rock fragments; the matrix is commonly enriched in kaolinite and illitemontmorillonite; and the cement is mainly composed of authigenic siderite and some iron oxide coatings. Interpretations of these characteristics suggest that the Chilga sediments were deposited in alluvial-lacustrine environment with a nearby fine-grained sediment source indicating a reducing diagenetic environment (Mulugeta Feseha, 2002).

This study presents results of sequence stratigraphic interpretation of the Chilga basin 
sediments from regional stratigraphic correlation, geochronology and depositional environment interpretation. Results indicate that the Chilga sedimentary basin has recorded three $4^{\text {th }}$ order sedimentary cycles formed by the expansion and contraction of the lake throughout its evolution.

\section{LOCATION OF THE STUDY AREA}

The Chilga basin, with an approximate areal extent of $14.8 \mathrm{~km}$ by $25.9 \mathrm{~km}$, is located in northwestern Ethiopia, between $\mathrm{N} 12^{\circ} 25^{\prime}$ to $12^{\circ} 39^{\prime}$ latitude and E $37^{\circ} 03^{\prime}$ to $37^{\circ} 11^{\prime}$ longitude (Fig. 1). Chilga basin is located about $100 \mathrm{kms}$ northwest of Lake Tana and it is part of the Tana basin.

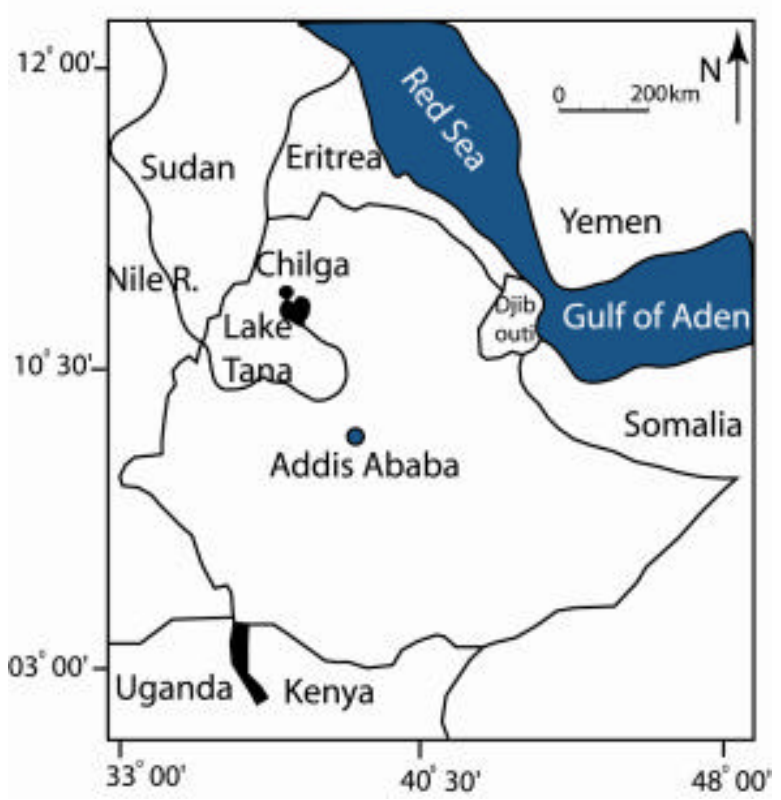

Fig. 1. Map depicting the location of Ethiopia in East Africa. The Chilga region is located in north-western Ethiopia (black dot), about $100 \mathrm{~km}$ northwest of Lake Tana.

\section{METHODOLOGY}

The Chilga basin sediments are exposed in four areas: Chilga west (W), Chilga east central (E-C), Chilga east (E), and Chilga north (N) (Fig. 2). Each exposure is isolated from the other by faults and basalts that erupted at a later stage. Lithologic units of each stratigraphic section were described and measured in the field and samples were collected from each lithologic unit for laboratory analysis. Petrographic and x-ray diffraction analyses were carried out on each collected sample and the mineralogical composition of each lithologic unit was identified (Mulugeta Feseha, 2002) allowing for facies classification and interpretation of the environment of deposition. The location of each measured and described stratigraphic section was recorded using global positioning system (GPS). Using 36 measured and described stratigraphic sections, stratigraphic correlation among the Chilga west, east central, east, and north exposures was carried out and this has helped to make regional stratigraphic correlation.

\section{RESULTS AND INTERPRETATION}

\section{Stratigraphic correlation and interpretation}

Regional stratigraphic correlation among the Chilga west, east central, east and northern exposures was possible from the thirty-six measured and described stratigraphic sections. The structural relationship between the different exposures was also identified and the stratigraphic relationship between the sediments and the underlying basalt was established.

The stratigraphic correlations of the Chilga west outcrops revealed five volcanic ash marker beds (IV) that can be correlated between sections, with lateral distance, up to three kilometres (Fig. 3). The lower three volcanic ash beds are altered, do not contain recognizable volcanic glass shards, are horizontally bedded, and do not display the distinctive suite of sedimentary structures such as ripples or cross bedding structures that would suggest they are the products of stream reworking. The wide geographical area across which the lower three volcanic ash beds are found and the absence of any fluvial sedimentary structures suggest that these ashes were aerially deposited. The upper two volcanic ash beds are also found across a large geographical region and they too are laterally continuous. In some areas the laterally continuous and the horizontally bedded ashes of ash-IV and ash-V have channel insertions that are also composed of volcanic ash. These channel deposited ashes have wave-ripples, fine laminations, and cross bedding structures, and they usually contain well-preserved volcanic glass shards. The main distinction observed between the ash-IV and ash-V in the Chilga west is the in situ presence of wellpreserved branch and leaf fossils in volcanic ash-IV that are not observed in volcanic ash-V. 


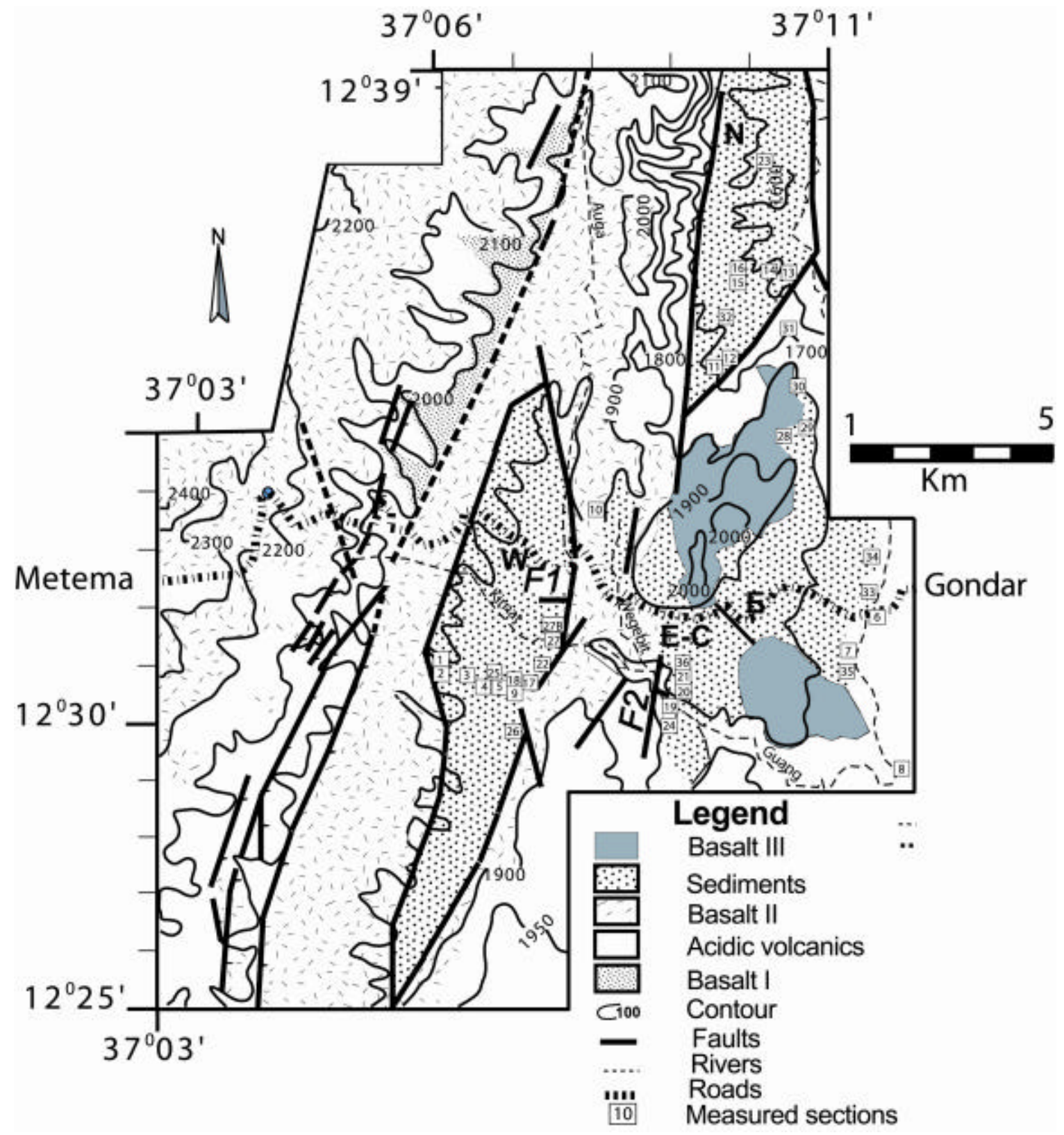

Fig. 2. The Chilga basin sediments are subdivided into west (W), east-central (E-C), east (E), and north (N) exposures. Fault "F1" separates the Chilga west exposures from basalt-II (horst structure); while fault "F2" separates Chilga eastcentral exposures from the same horst; and Chilga E and E-C are separated by the dark-line in between them. 36 measured and described stratigraphic sections from the Chilga north, west, east and east-central exposures are shown in numbers. Map modified from Belachew Tezera and Heeman (1983).

The sedimentary successions found between the five volcanic ash beds are mainly composed of silty clays, lignite beds, and silty sandstones, and can be classified into six units by using the volcanic ash as marker beds (Fig. 3). The first or lowest sedimentary sequence is dominantly composed of silty clays, few lignite units, and silty sandstone. It is underlain by basaltic rock and capped by the aerially deposited ash-I. The second sedimentary unit is composed of silty clays, lignite units, and silty sandstones. It is underlain and overlain by aerially deposited ash-I and ash-II respectively. The third sedimentary unit is composed of silty clays, lignite units, and silty sandstones and is underlain by ash-II and overlain by aerially deposited ash-III. The fourth sedimentary unit is also composed of silty sandstones, lignite units, and silty clays. It is underlain by ash-III and 
overlain by aerial and stream deposited ash-IV. The fifth sedimentary unit is dominantly composed of silty sands, lignite units, and silty claystones. It is underlain by ash-IV and overlain by aerial and stream deposited ash-V. Similarly, the sixth sedimentary unit is composed of silty clays and volcanic ashes and is underlain by ash- $\mathrm{V}$ and overlain by a silty clay unit. Sequence stratigraphic interpretation of these units shows that they belong to three sedimentary packages. Sedimentary package-I refers to all the sedimen- tary units from the bottom part of the succession up to and including the flooding surface above volcanic ash III; sedimentary package-II refers to sedimentary succession overlying volcanic ash-III up to and including flooding surface above the silty sand units overlying volcanic ash-IV; and sedimentary package III refers to sedimentary succession overlying the silty sand units above volcanic ash-IV, up to and including volcanic ash$\mathrm{V}$ (see sequence stratigraphic interpretation of the Chilga basin of this manuscript).

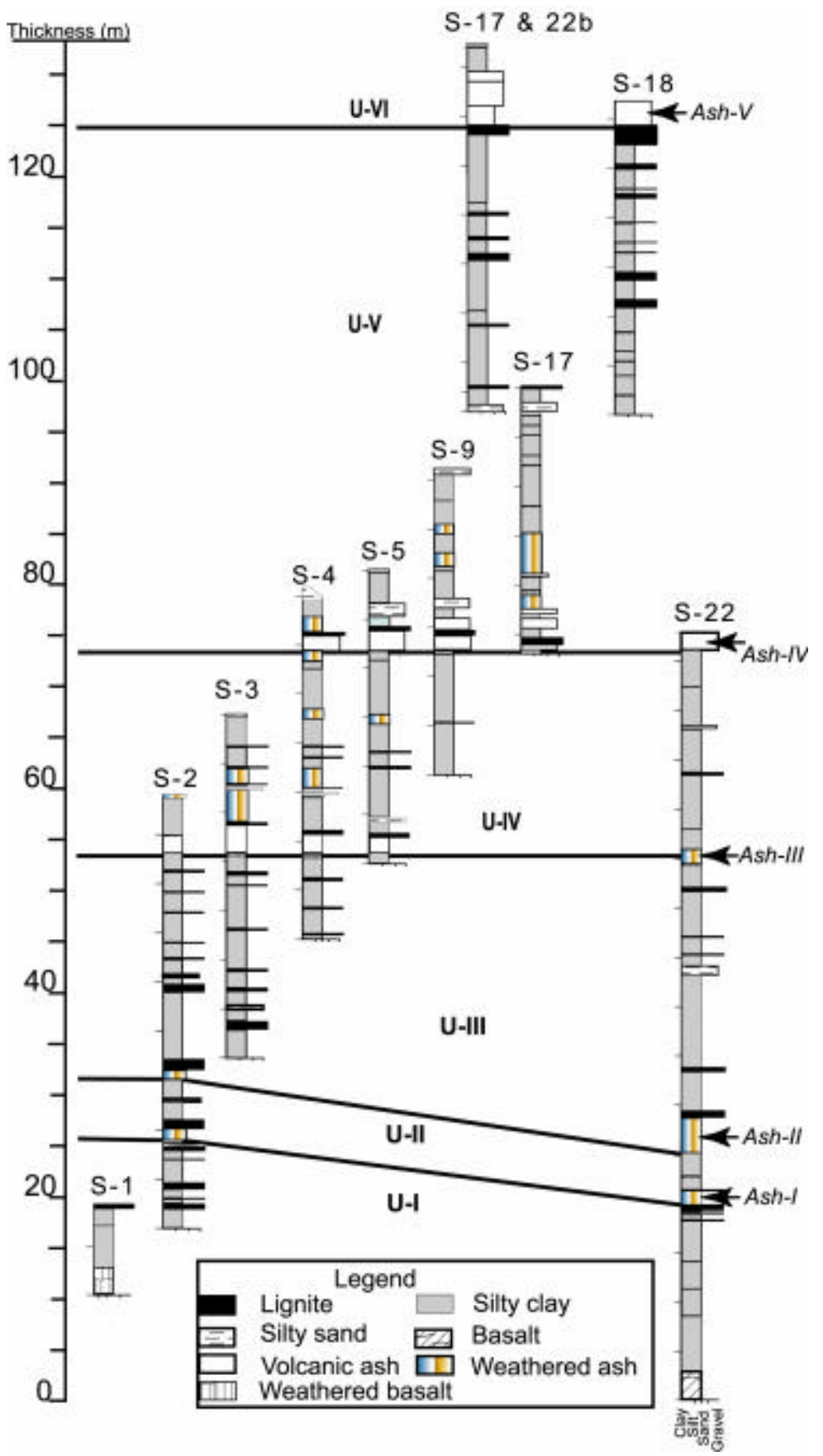

Fig. 3. Stratigraphic correlations in the Chilga west exposures are based on the volcanic ash beds (dark lines) and can be used to subdivide the sediments into six units. The letter "S with number" indicates the individual measured stratigraphic sections shown in Figure 2. 
A north-south trending normal fault (F1 in Fig. 2) separates the Chilga west sedimentary outcrops (W) from exposures of a basalt flow to the east. These faults cut the Chilga west sedimentary outcrops and the sediments are tilted by about 15 degrees to the west (Fig. 4). The basalt terrain, part of what was named Basalt II by Belachew Tezera and Heeman (1983) (Fig. 2), is an uplifted horst structure that also separates the western Chilga exposures $(\mathrm{W})$ from the east-central exposures (EC). A second north-south trending fault (F2 in Fig. 2) separates the Basalt II horst from the east-central Chilga exposures (Fig. 5).

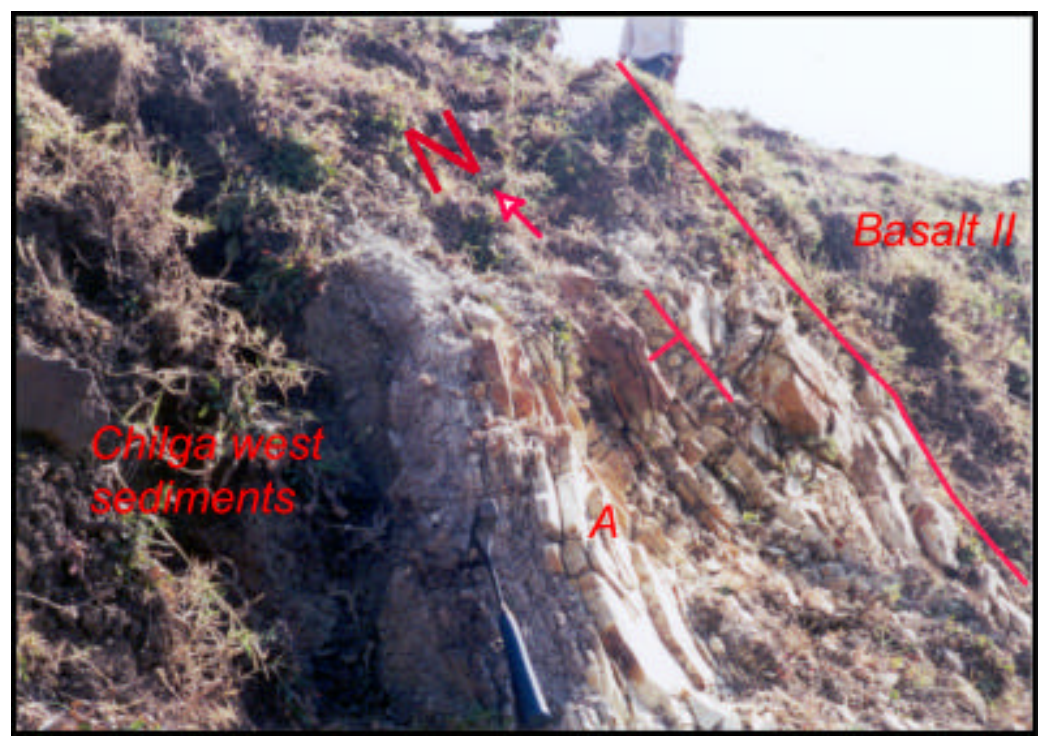

Fig. 4. The north-south trending normal fault (long dark line), separates the Chilga west exposures from the Basalt II horst structure exposed along its eastern margin. Ash bed V (A) is about $3 \mathrm{~m}$ thick and has been sheared by the fault, and dips west. The north direction $(N)$ is shown by the arrow. The GPS location of the photo is N12 ${ }^{\circ} 31$ '34.2" and E3 $7^{\circ} 06^{\prime} 33.4^{\prime \prime}$. Strike and dip of the ash bed is shown by the strike and dip symbol. Hammer at the bottom centre of the picture is for scale.

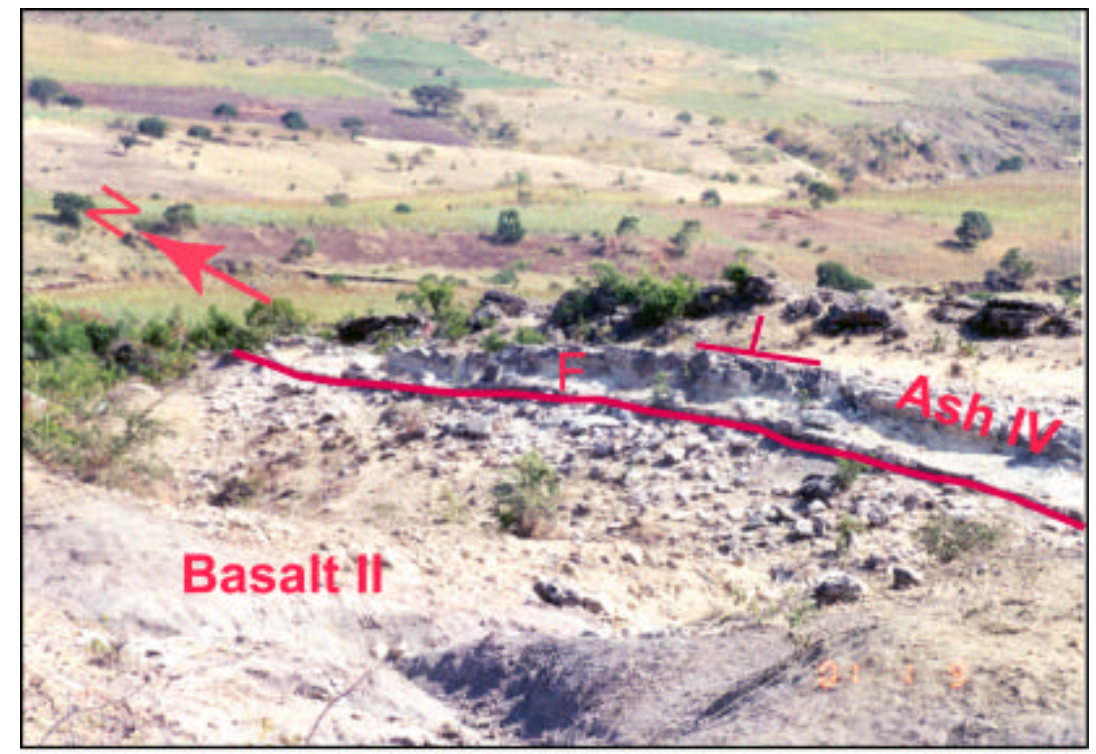

Fig. 5. The north-south trending normal fault (line with F) separates the Basalt II horst structure from the east-central Chilga sediment exposures. The east-central sediments have ash-IV at their base and dip toward the east. The thickness of Ash IV is $3.5 \mathrm{~m}$ thick in this photo. Strike and dip of the ash bed is shown by the strike and dip symbol. The GPS location of the site where the picture was taken is N12 $30^{\prime} 8.5^{\prime \prime}$ and $\mathrm{E} 37^{\circ} 09^{\prime} 0.2^{\prime \prime}$. 
The Chilga east-central sedimentary succession begins with ash IV (with locally abundant fossil plants) which lies on top of a weathered basalt, Basalt II (Fig. 6). Ash-IV is overlain by a silty clay, silty sand and lignite succession and continues upwards to include ash- $\mathrm{V}$ as the youngest bed in this succession (Fig. 7). Capping the east-central Chilga sediments is the Basalt III, the stratigraphically youngest but as yet undated basalt flow in the entire Chilga basin (Basalt III in Fig. 2).

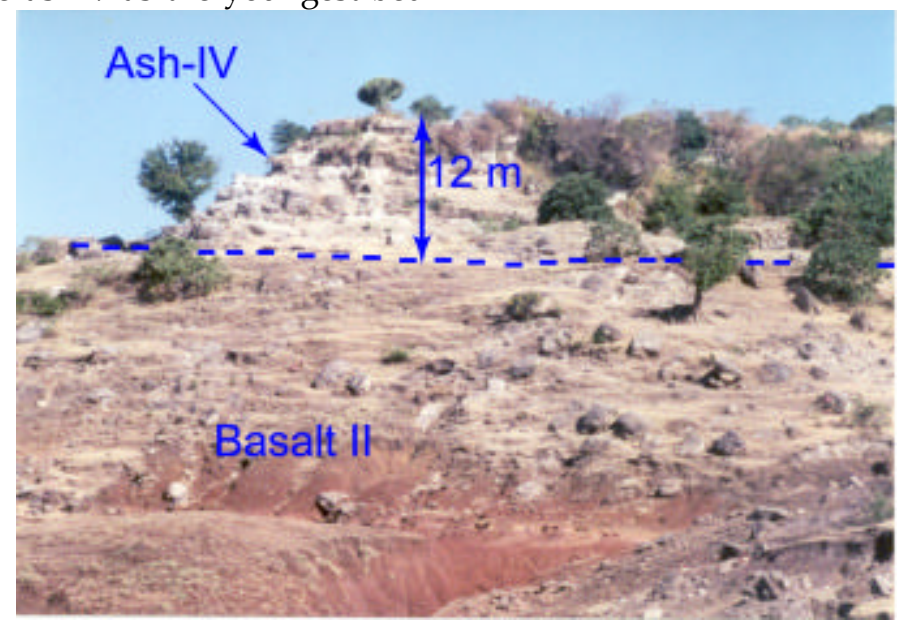

Fig. 6. Ash-IV is conformable with the highly weathered Basalt-II in the Chilga east-central exposure. The GPS location of the section where the photo was taken is N12 ${ }^{\circ} 30^{\prime} 54.4^{\prime \prime}$ and $\mathrm{E} 37^{\circ} 09^{\prime} 9.9^{\prime \prime}$.

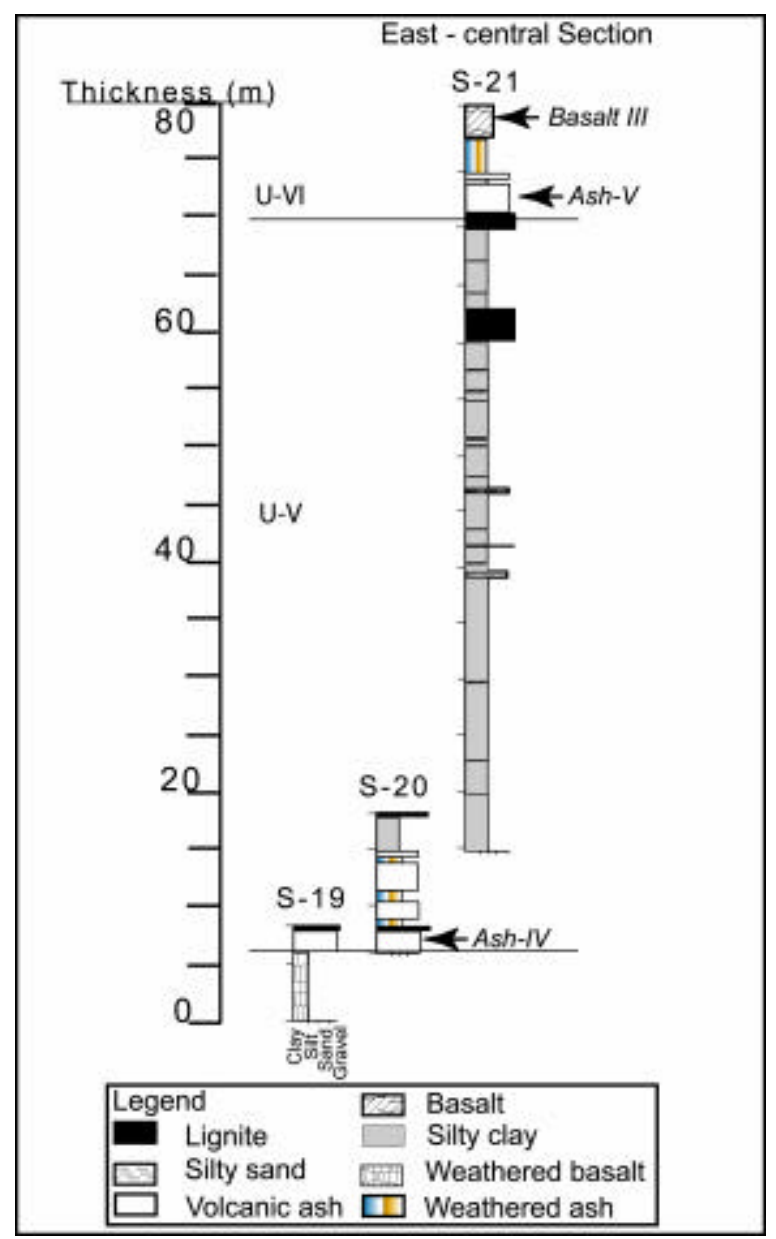

Fig. 7. Exposures in the Chilga east-central (E-C) area have a volcanic ash at their base that is overlain by silty clay, silty sand and lignite units, includes a second volcanic ash, and is capped by basalt III. The lowest ash in these exposures is correlated with volcanic ash-IV of the Chilga west exposures. Both volcanic ashes observed in these exposures are aerially and stream deposited. The letter " $S$ " stands for section and the numbers refer to the individual measured stratigraphic sections shown in Figure 2. 
The laterally continuous ash IV is used as the basis for the correlation between the Chilga eastcentral and east successions. As seen in the other exposures, ash IV in the east exposures is also locally rich in fossil plants and is overlain by successions of silty clay, sandy silt, lignite units and capped by volcanic ash V (Fig. 8).

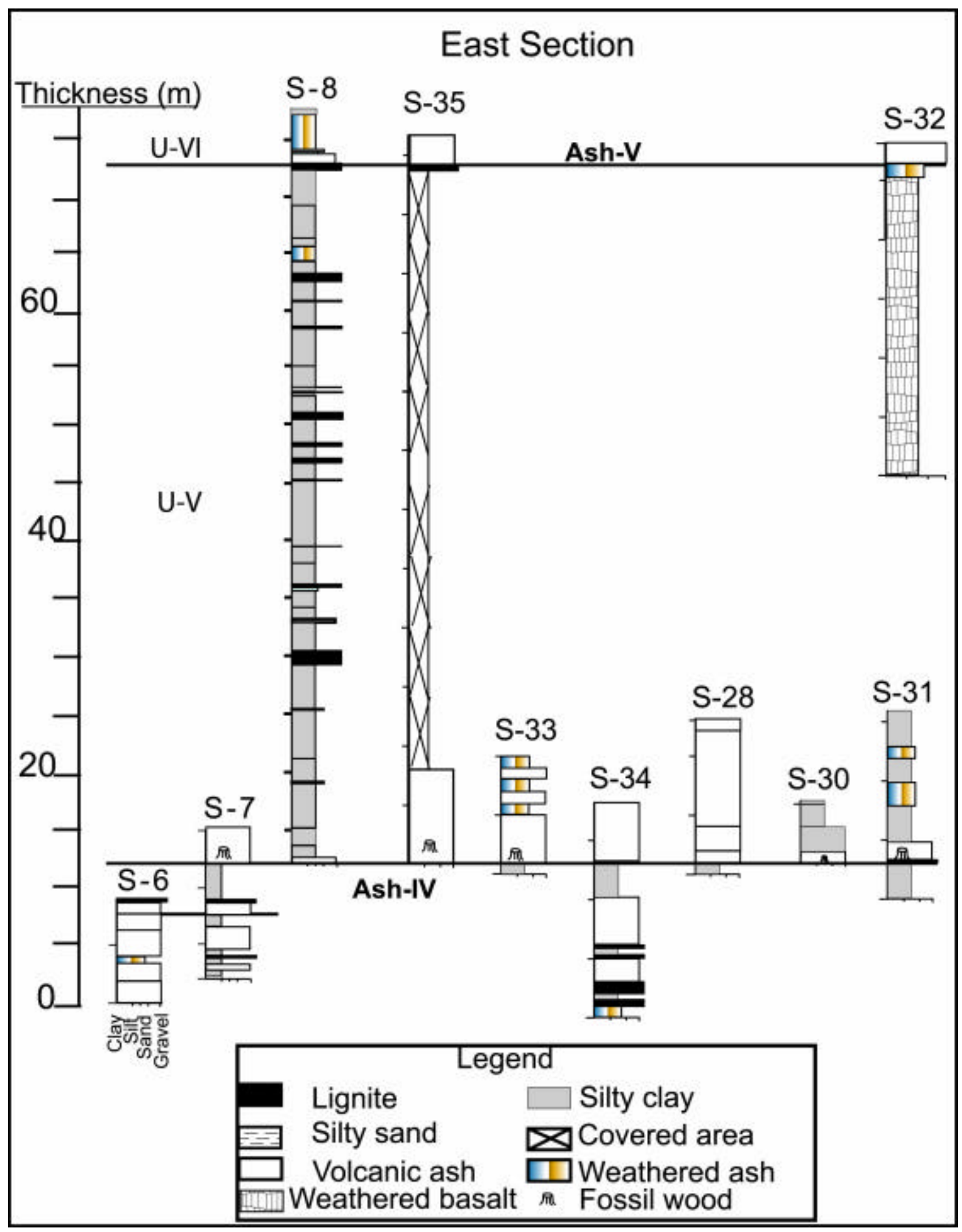

Fig. 8. The exposed sections in Chilga east generally show a volcanic ash at their base that is overlain by a silty clay, silty sand and lignite succession and capped by another volcanic ash. The basal ash is locally rich in well-preserved plant fossils. This ash is laterally continuous and serves as the basis for the regional stratigraphic correlation among the Chilga east, east-central, and north exposures. It is correlated with ash IV in the west. The letter " $\mathrm{S}$ " indicates the individual measured and described stratigraphic sections shown in Figure 2. 
Volcanic ash IV is also used to establish the correlation between Chilga east and north exposures. Unlike the Chilga east-central and east sequences, the Chilga north exposures (Fig. 9) preserve sedimentary succession that starts from ash I up to ash V, similar to what is observed in the Chilga west exposures. In the north succession five volcanic ash beds and associated silty clay, silty sand, and lignite units are recognized (Fig. 9). The overall sediment succession in the Chilga north exposure is generally similar to the west exposures, but there are no channel deposited volcanic ashes in the Chilga north exposures and the sediments between the weathered basalt and ash I that are observed in the Chilga west are not observed in the Chilga north. Additionally, ash I in the Chilga north is altered to white smecitic clay.

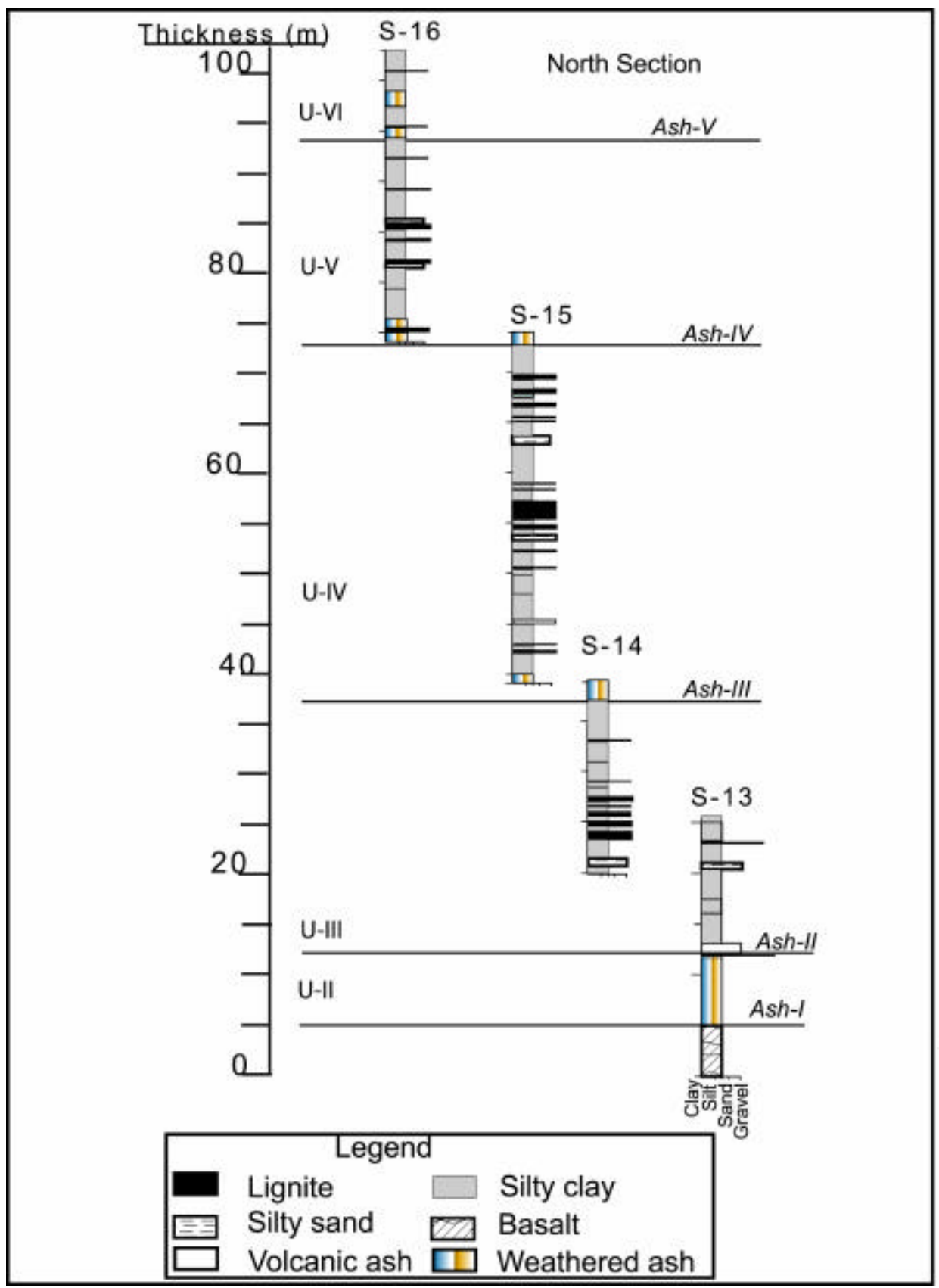

Fig. 9. The stratigraphic sections in the Chilga north exposures are correlated with volcanic ashes III and IV. The sections are divided into five units that are in turn correlated with units II through VI in the west. The letter " $S$ " indicates the individual measured stratigraphic sections shown in Figure 2. 
The regional stratigraphic correlation and interpretation shows that the Chilga north and western successions contain a relatively complete sedimentary record deposited on basal weathered basalt. The sedimentary succession is composed of silt clays, volcanic ashes, lignite beds, and silty sandstones (Fig. 10). The Chilga east-central and east exposures contain only the youngest sedimentary succession from volcanic ash IV through ash $\mathrm{V}$ (Fig. 10). The stratigraphic correlations along with the tectonic interpretation (Mulugeta Feseha, 2002) of the Chilga basin indicates the presence of paleo-highs separating Chilga north and west from the Chilga east-central and east areas (Fig. 10). During the earliest period of the Chilga sediment deposition (that is, prior to the deposition of volcanic ash IV), the Chilga north and west areas were active as paleo-depositional centres while the Chilga east and east-central areas were paleo-highs. Some time before the deposition of volcanic ash IV, a large-scale regional subsidence occurred and the lake increased in size to overlap the paleo-highs and join Chilga west, north, east central, and east together as a single basin (Mulugeta Feseha, 2002).

Magnetostratigraphic correlations of the Chilga west and north successions (Mulugeta Feseha, 2002) suggest that the sediments in these two areas were deposited at roughly the same time. Whether the Chilga north and west deposits were originally part of a single basin has not yet been established. However, once the paleo-high that separated Chilga west and north from east-central and east was on lapped, before the deposition of ash IV, the basin increased in size.

\section{Lithologic types, lithologic associations and depositional environment}

Silty claystones rich in kaolinite and illitemontmorillonite; silty sandstones rich in plagioclase feldspar, potassium feldspar, and volcanic rock fragments; lignite beds; and aerial and stream reworked and deposited volcanic ashes are the dominant lithologic units in the Chilga basin (Mulugeta Feseha, 2002). The silty sandstones and silty claystones are enriched in kaolinite, illite-montmorillonite and some reworked smectite clays and in most cases cemented by micritic to fine sand size siderite. The presence of siderite in the silty sandstones and claystones indicates the formation of the silty sandstones and claystones in an organic rich reducing diagenetic environment. The occurrence of lignite beds indicates that the environment was conducive for the preservation of organic matter. As suggested by several authors (Teichmuller, 1989; Moore and Reynolds, 1997), the conditions required for the preservation of organic matter are: 1) biomass accumulation, 2) minimum clastic influx, 3) ample accommodation space, and 4) the deposition of organic matter in a reducing environment (below the water table). Of the five volcanic ash layers in the Chilga basin the lower three (ash I to III) proved to be altered to smectite whereas the topmost two ash layers (ash IV to V) are less altered and have preserved volcanic glass shards.

The stratigraphic relationships between the lignite beds, silty claystones and volcanic ashes suggest that there are four distinct lithologic associations in the Chilga sedimentary basin. The most common lithologic association is that of lignite beds that are underlain and overlain by silty claystones. The second type of lithologic association is that of volcanic ashes that are underlain and overlain by silty claystones. A third type of association is that of lignite beds that are underlain by volcanic ashes showing evidence of aerial deposition and stream reworking and overlain by silty claystones. Finally the fourth type of association is that of lignite beds underlain by silty claystone and overlain by aerial deposited volcanic ashes associated with channelized flow and stream reworking. The stratigraphic relationship of these lithologic associations is shown in Fig. 11.

Detailed interpretation of these lithologic associations and their respective environments of deposition are described below. 


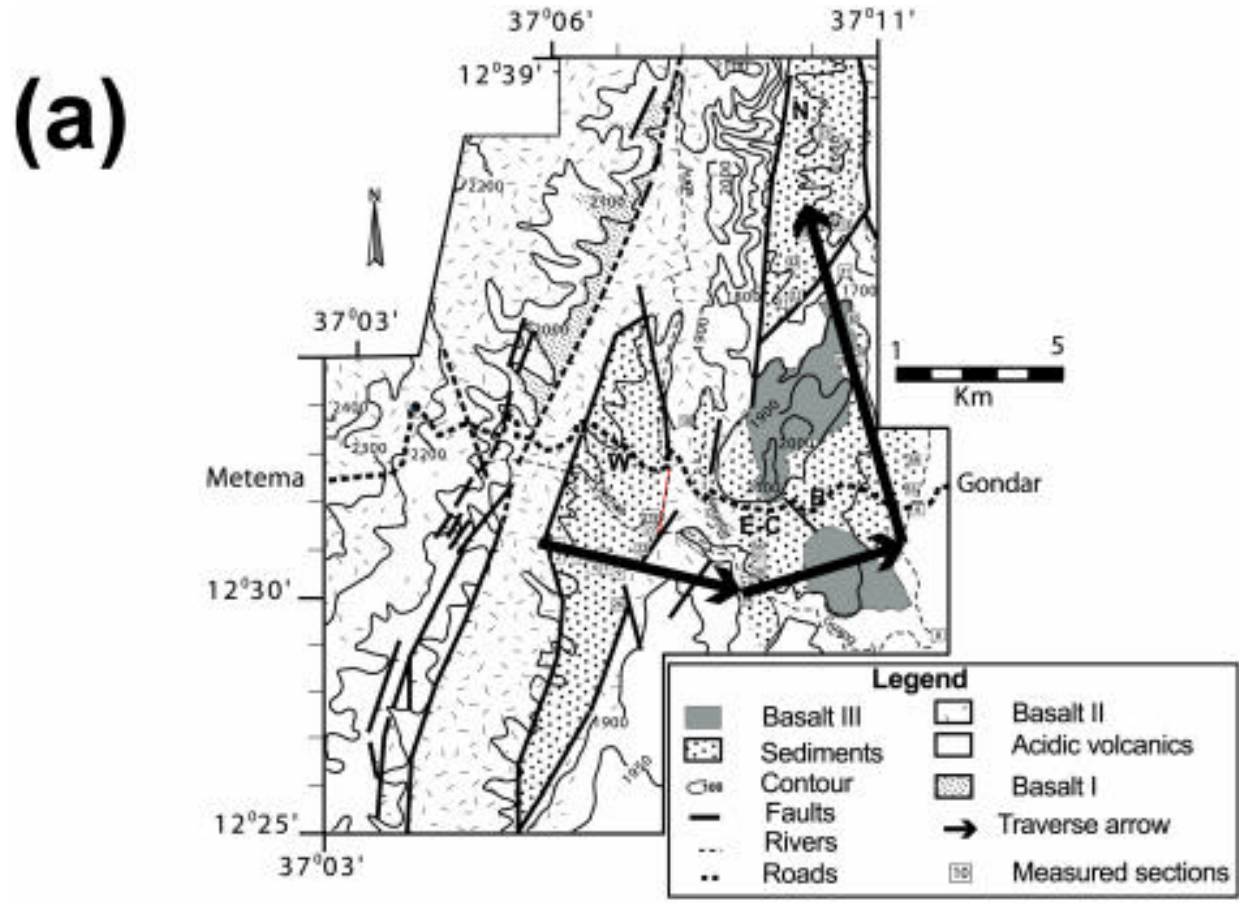

(b)

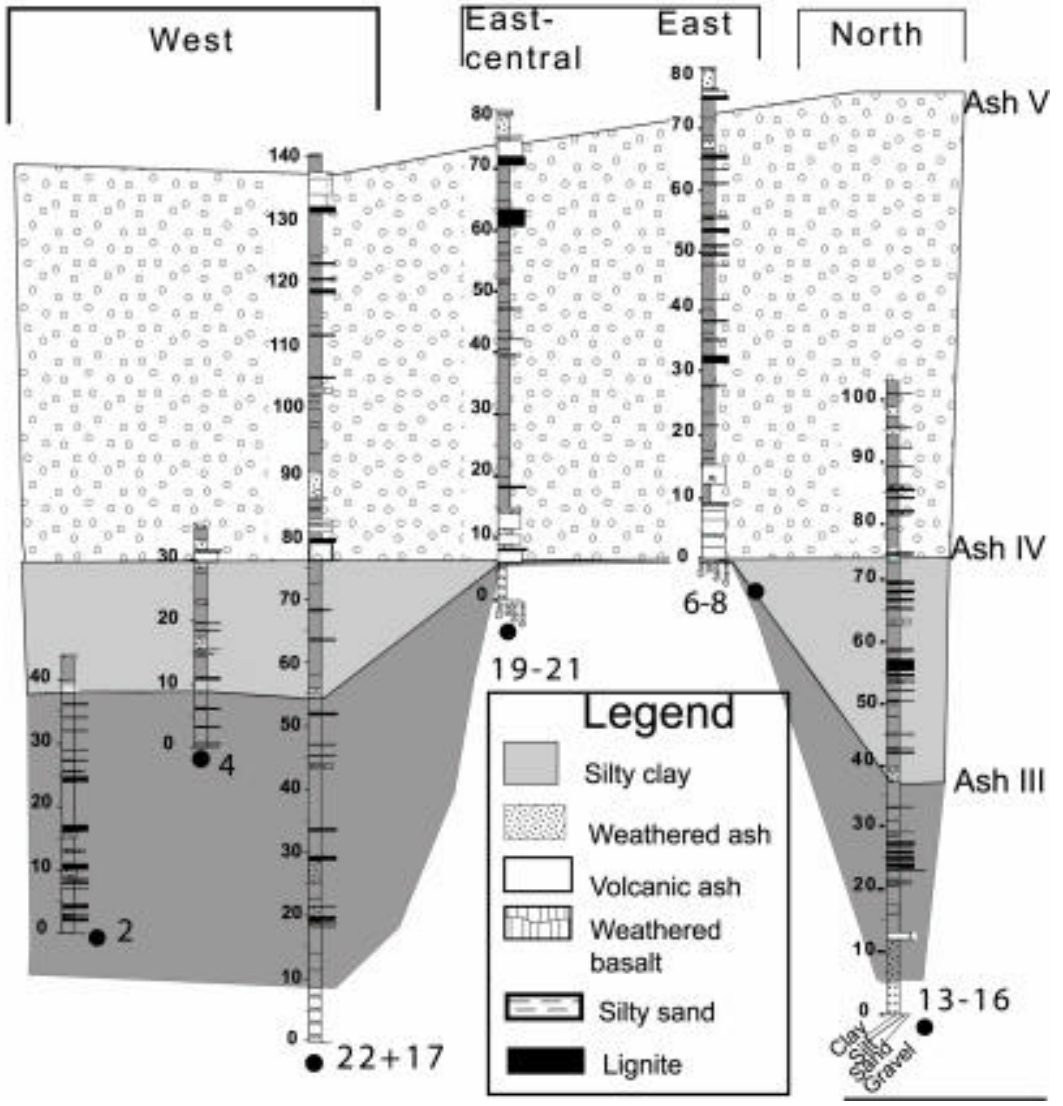

Fig. 10. (a) Top map shows traverses (arrows) made on the Chilga basin to make regional stratigraphic correlation among the various exposures. Sections 2, 4, 17, 22, 19-21, 6-8, 13-16 were considered. (b) The shades in the bottom map represent various stages of basin evolution. Chilga north and west were sites of deposition throughout most of the history of this basin, whereas Chilga east-central and east were paleo-highs during the early stage of sediment deposition. Subsequent large-scale regional subsidence, just before the deposition of ash IV, joined the different areas into a single basin. 


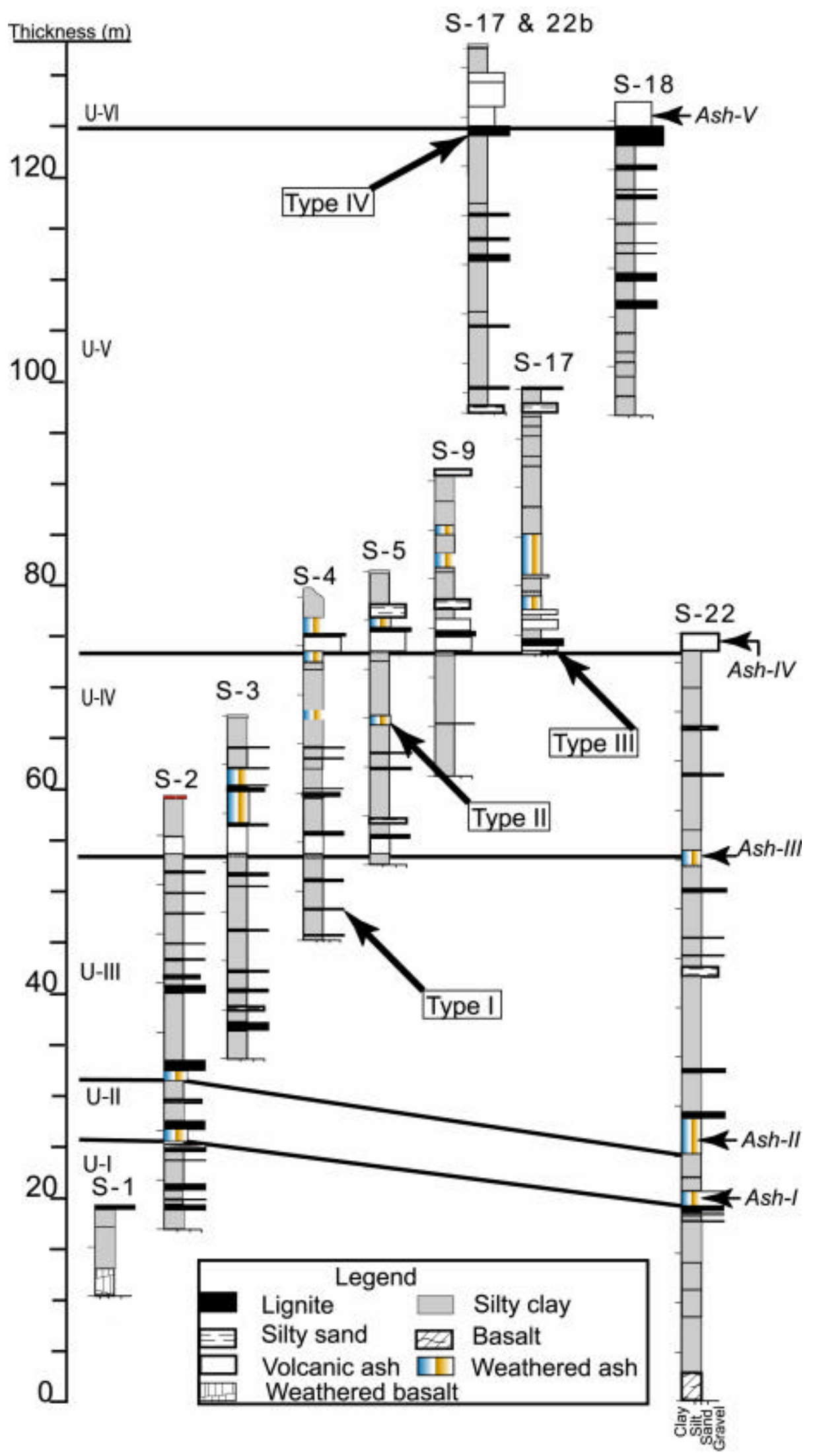

Fig. 11. Stratigraphic relationships of lignites, volcanic ashes and silty clays observed in the Chilga basin. The associations are the following: Type I refers to a lignite bed underlain and overlain by silty clays; type II refers to an ash bed underlain and overlain by silty clays; type III refers to a lignite bed underlain by ash bed(s) and overlain by silty clays; and type IV refers to lignite beds underlain by silty clays and overlain by ash bed(s). 
Type 1 lithologic association: lignite beds underlain and overlain by silty claystone

This lithologic association is common in the Chilga basin. Lignite beds underlain and overlain by siderite-rich silty clay units indicate the presence of three phases of change in water depth and sediment formation. The presence of sideritecemented silty claystone underlying the lignite indicates an increase in water depth and the formation of shallow-lake sediments. Lignite beds overlying the lake sediments indicate a shallowing of the lake and a significant increase in accommodation followed by the production and deposition of organic matter in an environment of reduced clastic influx. Similarly, the presence of the sideritecemented silty claystones overlying the lignite beds indicates an increase in water depth, the deposition of the silty claystones burying and preserving the organic matter.

Type 2 lithologic association: volcanic ashes underlain and overlain by silty claystone

Volcanic ashes underlain and overlain by silty claystones are common in the Chilga basin. These ashes are mostly altered and they do not preserve volcanic glass shards. Some of the ash beds have distinct features such as contorted bedding and fluidization structures (Mulugeta Feseha, 2002). Siderite-cemented silty claystones underlying and overlying the volcanic ashes indicate that the deposition of lake sediments was interrupted by the eruption and deposition of volcanic ashes. The presence of fluidization and contorted bedding structures in some of the volcanic ashes indicate that the volcanic ashes were rapidly deposited on top of the muddy lake sediments. These distinctive structures form when water escapes from the underlying sediments. Under these circumstances the volcanic ashes do not provide any evidence for a rise or fall in lake level. It can only be inferred that a volcanic eruption or an intrabasinal reworking supplied the ash.

Type 3 lithologic association: lignite beds underlain by volcanic ashes (that are in lateral continuity with channel deposited ashes) and overlain by silty claystones

In this lithologic association the volcanic ashes are generally laterally continuous and can be traced for up to three kilometres across the basin. In most cases these ashes are horizontally bedded and massive and they are interpreted to have been aerially deposited. These ash beds are laterally continuous with stream deposited ash-filled channels that cut into a laterally continuous ash bed. These volcanic ash-filled channels are laterally accreted and they have trough cross stratification, wave ripples, and fine lamination structures. The presence of this underlying aerial and stream deposited volcanic ashes indicates that the eruption and deposition of these volcanic ashes was contemporaneous with lake level fall and channel incision. The lignite beds overlying the volcanic ashes (in lateral continuity with the channel-associated ashes) correspond to an extended period of pronounced plant sedge growth along the lakeshore-and low clastic influx that resulted in the accumulation of the organic matter. Siderite-cemented silty clay units overlying the lignite beds indicate a rise in lake level and formation of lake sediments that buried the organic matter.

Type 4 lithologic association: lignite beds underlain by silty claystone and overlain by volcanic ashes that are associated with channellized flow

Lignite beds underlain by silty claystones and overlain by volcanic ashes are also observed in the Chilga basin (Fig. 11). The presence of the underlying siderite-cemented silty claystones indicates an increase in water depth and deposition of lake sediments. Lignite beds overlying the siderite-cemented silty claystone indicate the shallowing of the lake, producing significant space for accommodation that in turn was followed by deposition of organic matter during a period of low clastic influx. The aerial and stream deposited volcanic ashes that overly the lignite beds indicate the eruption and deposition of the ashes was contemporaneous with a significant fall in lake level as evidenced by channel incision and deposition of channel ashes as observed in many exposures. The occurrence of lignite beds that are overlain by channel deposited volcanic ashes indicates that the lake level was continuously falling. The above four lithologic associations and their respective interpretation for the environment of deposition is summarized in Fig. 12. 


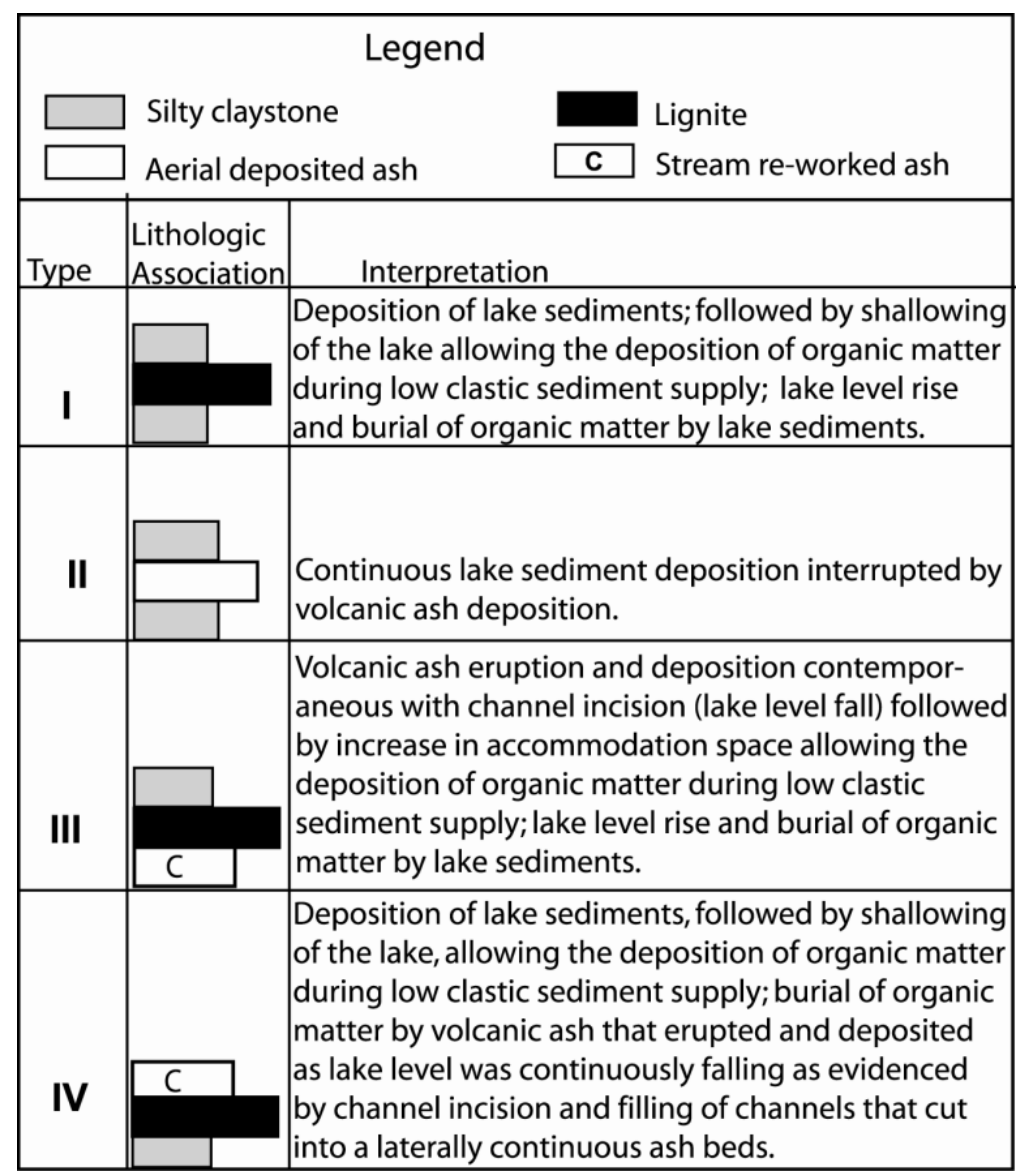

Fig. 12. Major lithologic associations recognized in the Chilga basin. The interpretation of their formation is determined by the rise and fall of the Chilga paleo-Lake throughout its evolution. The presence of aerial and stream re-worked volcanic ashes associated with the lignite and silty clay units indicate the presence of volcanic ash eruptions at different stages during the basin evolution.

Sequence stratigraphic interpretation of the Chilga sedimentary basin

A study of the individual Chilga lithologic units and their associations, regional stratigraphic correlations, depositional environment interpretation and geochronology are critical for interpreting the Chilga sequence stratigraphy. The presence of a relatively complete stratigraphic record with well exposed sedimentary outcrops that enable one to see vertical and lateral lithologic variation was very important for the sequence stratigraphic interpretation. The Chilga west and north exposures are the ones that have a relatively more complete sedimentary record. Moreover, The Chilga west exposures have relatively better exposed outcrops that show lateral and vertical lithologic variations, fairly recognizable facies changes and channel deposits when compared with the other Chilga exposures. Because of the above reasons, the Chilga sequence stratigraphic interpretation is mainly inferred from the Chilga west exposures.

Because the Chilga sediments are predominantly fine-grained, the facies interpretations relied heavily on petrographic and x-ray diffraction analyses described in Mulugeta Feseha (2002). Petrographic and x-ray diffraction analyses reveal that the silty claystones, silty sandstones, and weathered ash units found towards the centre of the basin are highly enriched in siderite cement, and this result suggests that they were formed under reducing conditions perhaps within a lake environment. As one moves towards the periphery of the lake, sediments lack siderite cement and are 
instead enriched in goethite and limonite. These results suggest the existence of more oxidizing environments. The analysis of the Chilga volcanic ashes has showed that the oldest three ashes are aerially deposited while the youngest two volcanic ashes are deposited both aerially and by stream reworking. This latter observation offers evidence for channel incision and lake level fall. A close examination of the Chilga lignite beds reveals that they have well preserved root structures that extend into the underlying beds. These observations indicate that the lignite beds represent in-situ plants that grew at the periphery in the shallow portion of the lake.

Sequence stratigraphic interpretation of the Chilga basin was inferred from the lateral and vertical stacking of stratigraphic units. In the sequence stratigraphic interpretation, the following key units were considered: a) the presence of siderite-cemented silty sands and silty clay units indicating increased water depth and the formation of siderite under shallow reducing conditions; b) in situ formation and preservation of lignite beds overlying siderite-cemented silty clay units indicating a phase of lake shallowing followed by accumulation and preservation of organic matter; c) presence of channel incisions indicating a time of significant fall in lake level; and d) the presence of siderite-rich mud units overlying channel incisions and palaeosols indicating flooding surfaces and these last evidences in turn are interpreted as sequence boundaries in the Chilga basin sequence stratigraphic interpretation.

Evidence from the lithologic associations and the sequence stratigraphic interpretation indicate that the Chilga sedimentary basin has recorded three $4^{\text {th }}$ order sedimentary cycles (Fig. 13), each of which is bounded by sediments that document a period of lake deepening that is followed by one of channel incisions and sub-areal exposure.

\section{Sedimentary cycle I}

Sedimentary cycle I (Fig. 13) comprises the basal member of the Chilga Formation. This sedimentary package starts with a weathered silty clay unit at its base that is in conformable contact with the underlying basalt. The silty clay unit is overlain by siderite-cemented lake sediments, which are interpreted as indicating the first phase of lake deepening. The siderite-cemented silty clay unit in turn is overlain by the first set of lignite beds. The presence of these lignite beds indicate a shallowing of the lake and increased abundance of vegetation along the lake periphery, low sediment influx as well as the deposition and burial of organic matter. The succession continues with alternating beds of silty claystone, silty sandstone, lignite and volcanic ash. Many times, the lignite beds are underlain by either silty clay or weathered ash. One obvious exception occurs with the third lignite bed because this unit is underlain by a well-developed paleosol horizon that contains well-preserved burrows and root structures. The presence of a well-developed paleosol horizon underlying a lignite bed indicates a phase of subareal condition and formation of soil. This was then followed by a significant rise in lake level covering marginal areas and a later development of plant materials that were buried by the successively rising lake level and deposition of lake sediments. The unique characteristics recognized in sedimentary cycle I is the presence of many short-term sub-cycles composed of interbedded silty clay, lignite, and volcanic ashes with short-term deepening and shallowing events. This inter-bedded succession continues up to the stratigraphic level of the third volcanic ash (Fig. 13). A closer examination of volcanic ash III reveals that toward the central part of the basin (see sections S-3, S-4 and S-5 in Figure 13) it is overlain by lignite whereas around the margin of the basin it is not (see section S-2 in Figure 13). This basinward migration of the lignite beds is an indication of significant shallowing of the lake, marking the end of the first sedimentary cycle.

During the first cycle, sediment was supplied by rapid influx of suspended load materials that offer no evidence of channel incision. It is also clear that the period of lake shallowing was marked by the growth and expansion of plants toward the basin centre, followed in turn by a rise in lake level and the subsequent deposition of lake sediments that buried the organic matter and produced shoalingupward units. 
.
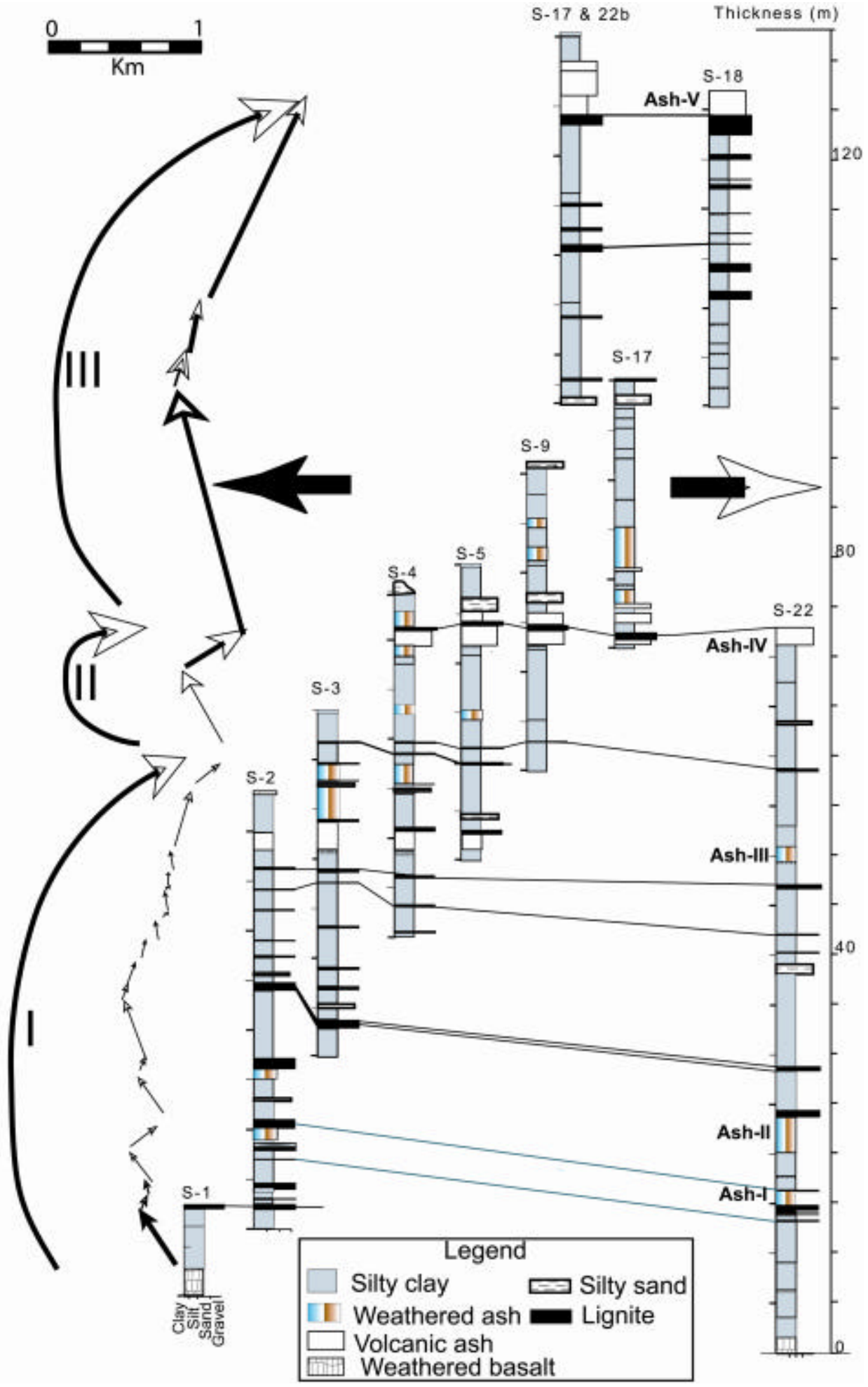

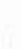

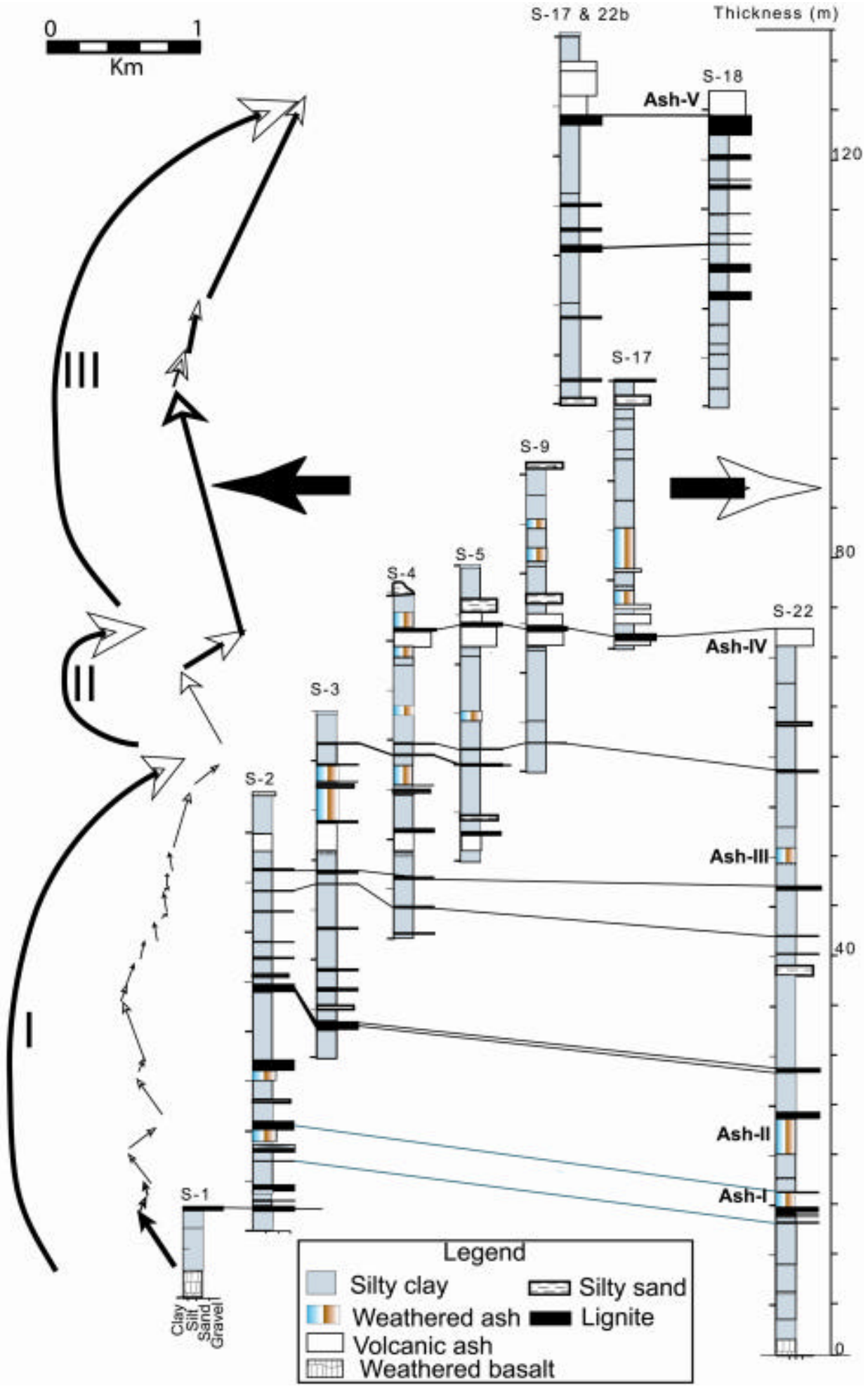

Fig. 13. The Chilga west exposures used for the Chilga basin sequence stratigraphic interpretation. Three sedimentary cycles formed by the rise and fall of the Chilga Lake. Curving lines show fourth order stratigraphic cycles and small arrows show smaller sub-cycles. Large black and white arrows show directions toward basin periphery and toward basin centre, respectively 


\section{Sedimentary cycle-II}

Sedimentary cycle II follows the first cycle and is capped by ash-IV [that has an $\mathrm{Ar}^{39} / \mathrm{Ar}^{40}$ age of 27 Ma (Mulugeta Feseha, 2002; Kappelman et al., 2003)] and overlain by silty sand unit. Sedimentary cycle II consists of a thick siderite-cemented silty clay unit at its base (that is interpreted as an indication of lake deepening) and overlies a paleosol horizon (which is interpreted as flooding surface and a sequence boundary). There are no lignite beds at the base of this sedimentary cycle, the absence of which indicates that there was a significant increase in depth of the lake (as also indicated by the thick silty clay unit), which presumably precluded lignite formation. The capping aerial and channel deposited volcanic ash IV indicates that its eruption and deposition was contemporaneous with lake level fall and channel incision. Silty sand units with average thickness of about 2-3 meters overlie the ash units. These units are the thickest silty sand units observed in the sedimentary succession (see sections 4, 5, and 9 in Figure 13 at about $45 \mathrm{~m}$ level) and show trough cross bedding and are filling channels that indicate a major fall in lake level and channel incision.

The duration of sedimentary cycle II appears to be relatively short-lived because it records a thinner sedimentary package than either cycles I or III. However, it shows clear evidence of a significant lake deepening followed by a sudden fall in lake level and channel incision. This record of a short-lived deepening event followed by an even more sudden period of shallowing indicates that an episode of major tectonic subsidence occurred in the Chilga basin before eruption of ash IV.

\section{Sedimentary cycle-III}

Sedimentary cycle III starts with a thick silty clay unit, overlying the flooding surface, which overlies the volcanic ash and silty sand channel units. The silty clay unit in turn is overlain by a succession of lignite beds and silty sandstones that are in turn capped by volcanic ash V (Fig. 13). The thick silty clay unit at the base of this sedimentary cycle corresponds to a significant increase in water depth as indicated by the deposition of thick lake sediments following the episode of shallowing at the end of sedimentary cycle II. The following successions of silty clays and lignites that overlay the basal silty clay unit indicate short-term subcycles that formed as a result of small-scale lake level rises and falls. The lignite beds are found toward the upper part of this cycle but are commonly found toward the centre of the basin and not at its periphery. This basin-ward occurrence of the lignite beds indicates a shallowing of the lake. Overlying the lignite beds is volcanic ash V; a unit deposited both aerially and by stream reworking. The presence of lignite beds that prograde towards the central part of the basin, along with the presence of channel deposited ash $\mathrm{V}$ which overlies a lignite, together indicate the final shallowing and drying of the Chilga lake and the end of sedimentary cycle III.

\section{CONCLUSION}

Petrographic and x-ray diffraction analysis of individual lithologic units, stratigraphic relationship of the lithologic associations, regional stratigraphic correlation, and depositional environment interpretation were used to interpret the sequence stratigraphy of the Chilga basin sediments. Sequence stratigraphy was inferred from the lateral and vertical stacking of stratigraphic units and the following key units were considered when classifying the stratigraphic succession into genetically related sedimentary packages: a) the presence of siderite-cemented silty sands and silty clay units indicating increased water depth and the formation of siderite under shallow reducing conditions; b) in situ formation and preservation of lignite beds overlying sideritecemented silty clay units indicating a phase of lake shallowing followed by accumulation and preservation of organic matter; c) presence of channel incisions indicating a time of significant fall in lake level; and d) the presence of sideriterich mud units overlying channel incisions and palaeosols indicating flooding surfaces and these last evidences in turn are interpreted as sequence boundaries in the Chilga basin sequence 
stratigraphic interpretation. Results of sequence stratigraphic interpretation indicate that the Chilga sedimentary basin has recorded three $4^{\text {th }}$ order sedimentary cycles, each of which is bounded by sediments that document a period of lake deepening that is followed by one of channel incisions and sub-areal exposure.

\section{REFERENCES}

1. Baker, B.H., Mohr, P.A. and Williams, L.A.J. (1972). Geology of the Eastern Rift System of Africa. The Geological Society of America, special paper 136:1-67.

2. Beadle, L.C. (1981). The Inland Waters of Tropical Africa, an Introduction to Tropical Limnology. Longman, New York, 475 pp.

3. Belachew Tezera and Heeman, W. (1983). Geological map of the Chilga area northwest of Lake Tana, 1:10,000. Ministry of Mines, Addis Ababa, Ethiopia.

4. Bohacs, K. and Suter, J. (1997). Sequence stratigraphic distribution of coaly rocks: fundamental controls and paralic examples. AAPG Bulletin 81:1612-1639.

5. Carroll, A. and Bohacs, K.M. (2000). Lake-type controls on petroleum source potential in nonmarine basins. AAPG Bulletin 6:1033-1053.

6. Contreras, J. and Scholz, C.H. (2000). Evolution of stratigraphic sequences in multi-segmented continental rift basins: Comparison of computer models with the basins of the East African rift system. AAPG Bulletin 9:1565-1581.

7. Hanson, D.A., Ritts, B.D., Zinniker, D., Moldowan, J.M. and Biffi, U. (2001). Upper Oligocene lacustrine source rocks and petroleum systems of the northern Qaidam basin, northwest China. AAPG Bulletin 4:601-619.

8. Kappelman, J., Rasmussen, D.T., Sanders, W.J., Mulugeta Feseha, Bown, T., Copeland, P., Crabaugh, J., Fleagle, J., Glantz, M., Gordon, A., Jacobs, B., Maga, M., Muldoon, K., Pan, A., Pyne, L., Richmond, B., Ryan, T., Seiffert, E.R., Sen, S., Todd, L., Wiemann, M.C. and Winkler, A. (2003). New Oligocene mammals from Ethiopia and the pattern and timing of faunal exchange between Afro-Arabia and Eurasia. Nature 426:549-552.
9. Lambiase, J.J. (1989). The framework of African rifting during the Phanerozoic. Journal of African Earth Sciences 8:183-190.

10. Lambiase, J.J. and Bosworth, W. (1995). Structural controls on sedimentation in continental rifts. In: Hydrocarbon Habitat in Rift Basins. The Geol. Society Special Publication 80:117-144.

11. Magee, J.W., Bowler, J.M., Mineraler, G.H. and Williams, D.L.G. (1995). Stratigraphy, Sedimentology, Chronology and Paleohydrology of Quaternary Lacustrine deposits at Madigan Gulf, Lake Eyre, South Australia. Paleogeography, Paleoclimatology, Paleoecology 113:3-45.

12. Mahboubi, A., Moussavi-Harami, R. and Lasemi, Y. (2001). Sequence stratigraphy and sea level history of the upper Paleocene strata in the Kopet-Dagh basin, northeastem Iran. AAPG Bulletin 5:839-859.

13. Mbede, E.I. (1991). The sedimentary basins of Tanzania-reviewed. Journal of African Earth Sciences 13:291-297.

14. Moore, D.M. and Reynolds Jr., R.C. (1997). X-ray Diffraction and the Identification and Analysis of Clay Minerals, 2nd ed. Oxford University Press, New York, 378 pp.

15. Morley, C.K. (1999). Geoscience in Rift SystemsEvolution of East Africa. AAPG Studies in Geology 44. AAPG, Tulsa.

16. Mulugeta Feseha (2002). Sequence Stratigraphy, Petrography and Geochronology of the Chilga Rift Basin Sediments, Northwest Ethiopia. Ph.D. Dissertation, Univ. Texas.

17. Mulugeta Feseha, Kocurek, G., Kappelman, J. and Copeland, P. (2001). Sequence Stratigraphy, Petrography and Geochronology of the Oligocene Chilga Rift Basin Sediments, Northwest Ethiopia. AAPG Annual Convention, Jun 3-6, Denver, CO, Abstract with Programs.

18. Pickard, M. (1994). Patterns of sedimentation and fossil distribution in the Kenya Rift Valleys. Journal of African Earth Sciences 18:51-60.

19. Pickard, M.D. and High, JR.L.R. (1981). Physical stratigraphy of ancient lacustrine deposits. The Society of Economic Paleontologists and Mineralogists, SEPM Special Publication 31:233259. 
20. Purser, B.H. and Bosence, D.W.J. (1998). Sedimentation and Tectonics in Rift Basins: Red sea-Gulf of Aden. Chapman and Hall, London, 663 pp.

21. Smith, M. (1994). Stratigraphic and structural constraints on mechanisms of active rifting in the Gregory Rift, Kenya. Tectonophysics 236:3-22.
22. Teichmuller, M. (1989). The genesis of coal from the viewpoint of coal petrology. International Journal of Coal Geology 12:1-87. 